\title{
Vitamin D Deficiency Is Correlated with Severity of Allergic Rhinitis
}

\section{Melati Sudiro ${ }^{*}$, Bony Wiem Lestari'2, Teti Madiadipoera1, Budi Setiabudiawan'3, Thaufiq Siddiq Boesoirie ${ }^{1}$}

\author{
${ }^{1}$ Department of Otolaryngology-Head and Neck Surgery, Faculty of Medicine, Universitas Padjadjaran/Hasan Sadikin Hospital, \\ Bandung, Indonesia \\ ${ }^{2}$ Department of Epidemiology and Biostatistics, Faculty of Medicine, Universitas Padjadjaran, Bandung, Indonesia \\ ${ }^{3}$ Department of Child Health, Faculty of Medicine, Universitas Padjadjaran/Hasan Sadikin Hospital, Bandung, Indonesia \\ Email: ^melati.sudiro@gmail.com, bony.wiem@unpad.ac.id, teti.madiadipoera@gmail.com, budi.setiabudiawan@unpad.ac.id, \\ tht_fkup@yahoo.com, melati.sudiro@gmail.com
}

How to cite this paper: Sudiro, M., Lestari, B.W., Madiadipoera, T., Setiabudiawan, B. and Boesoirie, T.S. (2017) Vitamin D Deficiency Is Correlated with Severity of Allergic Rhinitis. Open Access Library Journal, 4: e3813.

https://doi.org/10.4236/oalib.1103813

Received: July 7, 2017

Accepted: August 12, 2017

Published: August 15, 2017

Copyright $\odot 2017$ by authors and Open Access Library Inc.

This work is licensed under the Creative Commons Attribution International License (CC BY 4.0).

http://creativecommons.org/licenses/by/4.0/ (c) (i)

Open Access

\begin{abstract}
Background: Vitamin D deficiency has been targeted as a cause of the increased incidence of allergic rhinitis. Many factors, including sun exposure, influence vitamin D levels. Indonesia is a country with abundant sunshine exposure throughout the year; therefore, Indonesian residents are not expected to have inadequate vitamin D levels. Objective: This study aimed to investigate whether vitamin $\mathrm{D}$ deficiency levels are correlated with disease spectrum among allergic rhinitis patients. Material and Method: A cross-sectional study was conducted in the Rhino-Allergy ORL-HNS Clinic at Dr. Hasan Sadikin General Hospital in Bandung, Indonesia, from March-June 2016. All subjects underwent skin prick tests and serum 25-hydroxy vitamin D levels examination. To measure the association between vitamin $\mathrm{D}$ deficiency level and severity of allergic rhinitis, a Rank-Spearman correlation test was used and significant level was determined when the p-value is $<0.05$. Results: A total of 46 allergic rhinitis patients (19 males, 27 females, aged $28.3 \pm 6$ years) were included in this study. $63 \%$ of allergic rhinitis patients had a severe vitamin $\mathrm{D}$ deficiency and $50 \%$ of them classified as having persistent moderate-severe based on ARIA-WHO classification. Vitamin D deficiency was found to be significantly correlated with severity of allergic rhinitis status $\left(r_{s}=-0.321 ; p=0.005\right)$. Conclusion: We found vitamin $\mathrm{D}$ deficiency was correlated with allergic rhinitis classification and a significant proportion of allergic rhinitis patients showed a severe vitamin D deficiency.
\end{abstract}

\section{Subject Areas}

Allergy \& Clinical Immunology 


\section{Keywords}

Allergic Rhinitis, Vitamin D Deficiency, Indonesia

\section{Introduction}

Allergic rhinitis, which is defined as inflammation after the exposure of allergens to nasal mucous membranes, is mediated by immunoglobulin $\mathrm{E}$ (IgE) and represents a global health problem. The characterized symptoms of allergic rhinitis include nasal obstruction, watery rhinorrhea, sneezing and nasal itching. Although allergic rhinitis is not life treating, morbidity from the condition can significantly impact quality of life, disrupting a patient's social life, sleep, school and work [1].

The prevalence of allergic rhinitis varies among countries, likely due to the geographical and aeroallergens differences. Allergic rhinitis affected 10\%-30\% of the population or more than 500 million people worldwide [1]. The prevalence of allergic rhinitis in Asia is as high as 45\%, primarily in low- and middle-income countries, including Indonesia. In adults, regional data show rates of $10 \%-32 \%$ for allergic rhinitis [2]. However, the prevalence which is influenced by genetic, geographic, climate factors and by a region's dominant allergens, differs across countries. A total of 167 patients with allergic rhinitis were examined at the Rhinology Allergy ORL HNS Clinic of Dr. Hasan Sadikin Hospital from 2010-2012. Most of the patients were 18 - 34 years old (52.7\%), 14.4\% were 35 49 years old and $52 \%$ suffered from moderate-severe persistent allergic rhinitis based on the Allergic Rhinitis and Its Impact on Asthma-World Health Organization (ARIA-WHO) [3].

It is known that cytokines and mediators are involved in the development of allergic rhinitis, Th2 are dominant cell type and produce Interleukin (IL)-4, IL-5, IL-9, IL-13 and granulocyte-macrophage colony stimulating factor (GM-CSF) which contribute to the inflammatory response [4] [5]. Vitamin D is a fatsoluble vitamin that acts as a steroid hormone and plays a role in calcium, phosphor and bone metabolism. Receptors of active form of vitamin D3 (1,25-dihydroxyvitamin D3) have been found in dendritic cell, monocyte, macrophage, lymphocytes, as well as other parts of the immune system immune system [6]. Several hypotheses have proposed that active form of vitamin D3 play a role in allergic pathogenesis through innate and adaptive immunity. 1,25-Dyhydroxyvitamin D3 has been shown and to promote Th2 activities and promotes IL-10 and Foxp3 (a regulatory T-cell profiles) expression [7] [8].

Regardless of the definition of vitamin D deficiency and insufficiency, many studied in different countries in South Asia and Southeast Asia have revealed widespread prevalence of vitamin D deficiency and insufficiency. For most people, the main source of vitamin D is sun exposure to the skin; approximately $10 \%$ of the population recieves vitamin D through ingested food [9]. Indonesia is 
a tropical country with sun exposure year-round; thus, people in Indonesia are not expected to have vitamin D deficiency. However, Setiati S et al., found that the prevalence of $25(\mathrm{OH}) \mathrm{D}$ deficiency among elderly Indonesian women in institutionalized care is about $35.1 \%$ [10]. Currently people spend more time indoors, leading to less sunlight exposure, use of sunscreen throughout the day, insufficient vitamin D intake from food.

In recent years, many published studies have examined the relationship between allergic diseases and low vitamin D levels. The Aim of this study was to investigate whether low vitamin D status in allergic rhinitis patients was associated with more severe clinical presentation at the compared to Rhinology-Allergy Clinic Dr. Hasan Sadikin Hospital Bandung-Indonesia.

\section{Methods}

We conducted a cross-sectional study with total recruitment consecutive sampling method among rhinitis patients who visited the Rhinology-Allergy ORL-HNS Clinic at Dr. Hasan Sadikin Hospital, Bandung, Indonesia during March to June 2016. This study included seventy-six patients (20 - 59 years old) with chief complain obstruction and runny nose. All patients were further examined to confirm their allergic rhinitis status according to the Allergic Rhinitis and its Impact on Asthma (ARIA) criteria and the skin prick test [1].

The allergic rhinitis diagnosis was established according to the ARIA-WHO 2008 criteria, which is based on the patient history (i.e., a minimum of 2 nasal symptoms, such as rhinorrhea, nasal obstruction, sneezing or nasal itching), [1] a consistent finding from anterior rhinoscopy and positive results for at least one of 6 aeroallergen extracts on a skin prick test. In this study, we managed to confirm allergic rhinitis diagnosis among 46 patients and the rest were considered as negative for allergic rhinitis, as determined by negative skin prick test results. All subjects underwent blood tests to determine their 25-hydroxyvitamin D levels. We measured patient height and weight and calculated the BMI according to the formula weight $(\mathrm{kg}) /$ height $\left(\mathrm{m}^{2}\right)$ for all subjects. The study was approved by the Health Research Ethics Committee Faculty of Medicine Universitas Padjadjaran Bandung (No: 218/UN6.C1.3.2/KEPK/PN/2016), and the subjects provided written informed consent.

Standardized allergen extracts (ALK-Abelló, Port Washington, NY-US-License) were used for the skin prick tests. Histatrol ${ }^{\varpi}$ (histamine base $1 \mathrm{mg} / \mathrm{ml}$ ) was used as the positive control, and a glycerinated phenol-saline control was used as a negative control and 6 common allergens (Dermatophagoides pteronyssinus, Dermatophagoides farinae, mixed aspergillus, cockroach, dog epithelium and cat hair) were applied using a Multi-Test $\mathrm{II}^{\odot}$ manufactures by Lincoln Diagnostic, Inc. USA. The results were read 15 minutes after the application. A wheal $\geq 3 \mathrm{~mm}$ in response to a positive control extract was considered to be positive, a wheal $<3 \mathrm{~mm}$ was considered a negative result. The serum concentration of $25(\mathrm{OH}) \mathrm{D}$ was measured with a Cobas E 411 electrochemiluminescence bind- 
ing assay (ECLIA). Blood was collected from all subjects. A vitamin D level of $<5$ $\mathrm{ng} / \mathrm{ml}$ was considered very severe vitamin $\mathrm{D}$ deficiency; 5 - $10 \mathrm{ng} / \mathrm{ml}$ was considered severe vitamin D deficiency; $10-20 \mathrm{ng} / \mathrm{ml}$ was considered deficiency, and $20-30 \mathrm{ng} / \mathrm{ml}$ was considered insufficient [6]. None of the participants received vitamin D supplementation.

The statistical analysis was performed using descriptive statistics (the mean, median and standard deviation) to evaluate the patient's characteristics. To measure the association between vitamin D deficiency level and severity of allergic rhinitis, a Rank-Spearman correlation test was used and significancy level was determined when the $\mathrm{p}$-value is $<0.05$.

\section{Results}

Among 76 patients included 31 (41\%) were male patients and 45 (59\%) were female patients; the mean age was $30.58 \pm 7.7$ years (range, 20 - 59 years). Fortysix $(60 \%)$ were confirmed as allergic rhinitis patients according to ARIA criteria and skin prick test. Sixty-three $\%$ of allergic rhinitis patients had a severe vitamin D deficiency and $50 \%$ of them classified as having persistent moderate-severe. Female patients comprised 27 (59\%) cases in the allergic group. We evaluated the age, gender, BMI and serum $25(\mathrm{OH})$ vitamin D levels. The mean vitamin D level in the allergic rhinitis group was $9.8 \pm 5.6 \mathrm{ng} / \mathrm{ml}$. The mean BMI in the allergic rhinitis was $24.6 \pm 4.1 \mathrm{~kg} / \mathrm{m}^{2}$ (Table 1 ).

Table 1. Characteristic between 25(OH)D vitamin level, age, and BMI in two study groups.

\begin{tabular}{|c|c|c|c|}
\hline Variable & $\begin{array}{c}\text { Allergic Rhinitis } \\
\text { Group } \mathrm{n}=46\end{array}$ & $\begin{array}{c}\text { Control Group } \\
\mathrm{N}=30\end{array}$ & p-value \\
\hline 1. $25(\mathrm{OH}) \mathrm{D}$ level & & & $0.008^{*}$ \\
\hline Very severe Deficiency $(<5 \mathrm{ng} / \mathrm{ml})$ & 3 & 11 & \\
\hline Severe Deficiency $(5-10 \mathrm{ng} / \mathrm{ml})$ & 29 & 14 & \\
\hline Deficiency $(11-19 \mathrm{ng} / \mathrm{ml})$ & 11 & 5 & \\
\hline Insufficiency $(20-30 \mathrm{ng} / \mathrm{ml})$ & 2 & 0 & \\
\hline Normal $(30-50 \mathrm{ng} / \mathrm{ml})$ & 1 & 0 & \\
\hline $\bar{x} \quad(\mathrm{SD})$ & $9.8(5.6)$ & $6.9(2.9)$ & \\
\hline Median & 8.4 & 6.3 & \\
\hline Range & $2.7-30.7$ & $2.3-13.4$ & \\
\hline 2. Age (yrs) & & & $0.003^{*}$ \\
\hline $\bar{x} \quad(\mathrm{SD})$ & $28.3(6.0)$ & $34.1(8.7)$ & \\
\hline Median & 28 & 33 & \\
\hline Range & $20-40$ & $21-59$ & \\
\hline 3. BMI $\left(\mathrm{kg} / \mathrm{m}^{2}\right)$ & & & $0.069^{* *}$ \\
\hline $\bar{x} \quad(\mathrm{SD})$ & $24.6(4.1)$ & $23.0(2.9)$ & \\
\hline Median & 24.5 & 22.6 & \\
\hline Range & $14.9-35.8$ & $17.8-30.2$ & \\
\hline
\end{tabular}

Note: $\bar{x}(\mathrm{SD})$ : mean (standard deviation). $\left.{ }^{\star}\right)$ Mann-Whitney test; ${ }^{* *}$ ) t-test with $\mathrm{p}<0.05$ significant. 
Table 2 shows forty-six (60.5\%) of the 76 patients had positive skin prick tests for at least one inhalant allergen (allergic rhinitis group), whereas 30 (39.5\%) showed negative skin reactions to all allergens (control group). In the skin prick tests, mites triggered the greatest reaction ( $80 \%)$, follow by cockroaches.

Forty-six subjects with allergic rhinitis were classified by severity as follows (based on the ARIA-WHO guidelines): moderate to severe intermittent (19.6\%), mild persistent (30.4\%), and moderate to severe persistent (50\%). A significant correlation found between a low vitamin $\mathrm{D}$ level, and the severity of allergic rhinitis $(\mathrm{p}=0.005 ; \mathrm{rs}=-0.321)$ shows in Table 3 .

\section{Discussion}

Vitamin D is a hormone that has multiple physiological effects. Accumulating evidence has demonstrated that vitamin $\mathrm{D}$ has significant effects on innate and adaptive immunity. In innate immunity, vitamin $\mathrm{D}$ inhibits pro-inflammatory cytokine production. Vitamin D also impacts the adaptive immune system by affecting T-cell activation and antigen-presenting cell function. The association between vitamin $\mathrm{D}$ levels and Th2 cells is less clear, and contradictory results have been reported; the immune-regulatory effects may result in increased or decreased expression of Th2 cytokines [11].

The present study was conducted to investigate the association between the

Table 2. Allergens variance of the allergic rhinitis group $(n=46)$.

\begin{tabular}{cc}
\hline Allergens characteristics & Allergic rhinitis group \\
\hline Dermatophagoides pteronysinnus & $37(80 \%)$ \\
Dermatophagoides farinae & $37(80 \%)$ \\
Mix aspergillus & $1(2.2 \%)$ \\
Cockroach & $17(37 \%)$ \\
Cat hair & $4(8.7 \%)$ \\
Dog epithelium & $1(2.2 \%)$
\end{tabular}

Table 3. Correlation between vitamin D level with Allergic Rhinitis Classification.

\begin{tabular}{cccccc}
\hline Vitamin D Level & \multicolumn{5}{c}{ Allergic Rhinitis Classification } \\
\hline & $\begin{array}{c}\text { Mild } \\
\text { Intermittent }\end{array}$ & $\begin{array}{c}\text { Moderate- } \\
\text { severe } \\
\text { Intermittent }\end{array}$ & $\begin{array}{c}\text { Mild } \\
\text { Persistent }\end{array}$ & $\begin{array}{c}\text { Moderate- } \\
\text { severe } \\
\text { persistent }\end{array}$ & \\
\hline $\begin{array}{c}\text { Normal }(30-50 \mathrm{ng} / \mathrm{ml}) \\
\quad \text { Insufficiency }\end{array}$ & 0 & 0 & 1 & 0 & $\mathrm{p}=0.005$ \\
$(20-30 \mathrm{ng} / \mathrm{ml})$ & 0 & 0 & 2 & 0 & $\mathrm{r}_{\mathrm{s}}=-0.321$ \\
$\quad \begin{array}{c}\text { Deficiency } \\
(11-19 \mathrm{ng} / \mathrm{ml})\end{array}$ & 0 & 1 & 5 & 5 & \\
$\begin{array}{c}\text { Severe Deficiency } \\
(5-10 \mathrm{ng} / \mathrm{ml})\end{array}$ & 0 & 7 & 14 & 8 & \\
$\begin{array}{c}\text { Very Severe Deficiency } \\
(<5 \mathrm{ng} / \mathrm{ml})\end{array}$ & 0 & 1 & 1 & 1 & \\
\hline
\end{tabular}

$\mathrm{r}_{\mathrm{s}}=$ rank Spearman correlation test. 
vitamin D serum levels of patients with allergic rhinitis and to compare those results with results from a control group. Vitamin D deficiency has been proposed as a cause of increased allergy symptoms in several studies [6]. Our study found that $98.7 \%$ of patients with nasal symptoms examined at the clinic had low vitamin D levels. Vitamin D production is affected by sun exposure, skin color, and limited food intake. This result is surprising because Bandung is a major city in Indonesia and receives sunlight exposure nearly every day. We suspect that the average age in both groups influenced the results $(30.58 \pm 7.7$ years) because people in this age group perform most of their work or daily activities in buildings, which limits sun exposure; therefore, it is not possible to obtain sufficient vitamin D from sun exposure. Another reason for this result is the slightly dark skin of Indonesians. The level of melanin pigment in the epidermal layer can reduce the skin's ability to produce vitamin D from sunlight. Indonesia is located on the equator; it receives abundant sunlight throughout the year and has a hot climate. Thus, sun protective behaviors, including applying sunscreen, using umbrellas, wearing long-sleeved shirts, or wearing long robes and head coverings for religious reasons (for women), affect the vitamin D status in this country. Our finding is similar to that of Puri S et al., who reported a > $70 \%$ prevalence of vitamin $\mathrm{D}$ deficiency in all age groups [12].

Our findings demonstrated a higher mean serum $25(\mathrm{OH})$ vitamin $\mathrm{D}$ level in the allergic rhinitis group than in the control group $(\mathrm{p}=0.008)$. This finding is inconsistent with the findings of similar studies. Yenigun A. et al. reported that the plasma level of vitamin D was lower in an allergic rhinitis group than in the control group $(7.33 \pm 3.61 \mathrm{ng} / \mathrm{ml}$ vs $13.37 \pm 5.42 \mathrm{ng} / \mathrm{ml})$ [13]. Vatankhah V. et al. identified a lower mean serum level of $25(\mathrm{OH})$ vitamin $\mathrm{D}$ in an allergic rhinitis group $(19.8 \pm 7.4 \mathrm{ng} / \mathrm{ml})$ than in the control group $(224.9 \pm 7.4 \mathrm{ng} / \mathrm{ml})$ [14]. The authors reported that patients in the allergic rhinitis group were vitamin D deficient, but none of the subjects in the control group were vitamin D deficient. In recent decades, some studies have suggested a relationship between the increasing incidence of allergic disease and vitamin D deficiency; however, these findings are still debated [15] [16]. A meta-analysis conducted by Kim et al. found that prior vitamin D levels were not associated with developing allergic rhinitis but were associated with the prevalence of allergic rhinitis in children [17]. In contrast to our findings, in Kim et al.'s study, the allergic rhinitis group had normal vitamin D levels $(30.7 \mathrm{ng} / \mathrm{ml})$, and the mean age of this group was $28.3 \pm$ 6.0 years. We suggest that the vitamin $\mathrm{D}$ level in adults is dependent upon their outdoor activities, ethinicity, more frequent consumption of seafood than other types of animal protein, repeated application or inadequate application of sunscreen, and skin color.

A skin prick test is recommended by the ARIA criteria to demonstrate an Ig-E mediated allergic skin reaction. Mites are the most coon allergens detected worldwide [1]. We detected D. pteronyssinus and D. farinae allergens (80\%) followed by cockroach allergens (17\%) in the present study. This result was found in a similar study. Yenigun et al., from Turkey, found that D. pteronyssinus 
(50\%), a tree mix (47.6\%) and cockroach (45.2\%) were dominant inhalant allergens [13]. Epidemiological studies have shown that the worldwide distribution of aeroallergens, such as dust mites and pollens, demonstrates geographical and seasonal variations. Because of their natural inclination for hot and humid environments, house dust mite allergen levels vary across regions, primarily based on environmental factors, such as temperature and humidity. House dust mites are the most common aeroallergen implicated in allergic individuals in Asian countries [18]. Bandung is a city with $60 \%-80 \%$ humidity and a favorable environment for house dust mites.

Vitamin D is an immunomodulatory steroid hormone with a unique action. It functions in immune regulation by blocking the induction of Th1 cytokines, particularly IFN- $\gamma$, but it also simultaneously enhances Th2 responses by enhancing IL-4 production. In antigen presenting cells, vitamin D displays a suppressive effect on humoral immunity. However, vitamin D also inhibits the innate immune system. Immature dendritic cells promote T-cell tolerance, whereas mature dendritic cells activate naïve T-cells [7] [19].

Vitamin D concurrently suppresses IL-12 and enhances IL-10 production in immature dendritic cells, which decreases Th1 responses and skews the immune response toward a Th2 response. [19] In our study, allergic rhinitis patients showed a significant correlation between the classification of allergic rhinitis and the severity of vitamin $\mathrm{D}$ deficiency $\left(\mathrm{p}=0.005 ; \mathrm{r}_{\mathrm{s}}=-0.321\right)$. This result suggests the importance of assessing vitamin D levels in allergic rhinitis patients. Other studies have supported this finding, including a study by Oren et al., [20] which suggested that patients with vitamin $\mathrm{D}$ deficiency have a higher risk of allergic rhinitis. Wjst et al. reviewed the association between serum vitamin D levels and allergies using the Third National Health and Nutrition Examination Survey (NHANES III) study. The authors suggested that allergic rhinitis increased with serum levels of vitamin $\mathrm{D}$ in all groups and could be observed at all ages, with more prominent effects in children [21]. Limitation of this study, we did not have any data about the lifestyle, duration of daily sun exposure, calcium intake or infection within last two weeks that can be affected vitamin D serum level.

\section{Conclusion}

The prevalence of vitamin D deficiency was high in Bandung, Indonesia, a city in a country with abundant year-round sun exposure. A correlation was found between the severity classification of allergic rhinitis and the severity of the vitamin D deficiency. Therefore, measuring serum levels of vitamin D should be considered in the routine assessment of allergic rhinitis patients. These findings may then guide researchers in evaluating the use of vitamin $\mathrm{D}$ as an adjuvant therapy for the treatment of allergic rhinitis.

\section{References}

[1] Bousquet, J., Khaltaev, N., Cruz, A.A., Denburg, J., Fokkens, W.J., Togias, A., et al. 
(2008) Allergic Rhinitis and Its Impact on Asthma (ARIA) 2008 Update (in Collaboration with the World Health Organization, GA(2)LEN and AllerGen). Allergy, 63, 8-160. https://doi.org/10.1111/j.1398-9995.2007.01620.x

[2] Pawankar, R., Bunnag, C., Khaltaev, N. and Bousquet, J. (2012) Allergic Rhinitis and Its Impact on Asthma in Asia Pacific and the ARIA Update 2008. World Allergy Organization Journal, 5, S212-S217. https://doi.org/10.1186/1939-4551-5-S3-S212

[3] Moeis, R.M., Sudiro, M. and Herdiningrat, S. (2014) Allergic Rhinitis Patient Charactheristics in dr Hasan Sadikin General Hospital Bandung Indonesia. Althea Medical Journal, 1, 75-80. https://doi.org/10.15850/amj.v1n2.350

[4] Pawankar, R., Mori, S., Ozu, C. and Kimura, S. (2011) Overview on the Pathomechanisms of Allergic Rhinitis. Asia Pacific Allergy, 1, 157-167.

https://doi.org/10.5415/apallergy.2011.1.3.157

[5] Sin, B. and Togias, A. (2011) Pathophysiology of Allergic and Nonallergic Rhinitis. Proceedings of the American Thoracic Society, 8, 106-114. https://doi.org/10.1513/pats.201008-057RN

[6] Hewison, M. (2012) Vitamin D and Immune Function: An Overview. The Proceedings of the Nutrition Society, 71, 50-61. https://doi.org/10.1017/S0029665111001650

[7] Cantorna, M.T., Snyder, L., Lin, Y.D. and Yang, L. (2015) Vitamin D and 1,25(OH)2D Regulation of T Cells. Nutrients, 7, 3011-3021. https://doi.org/10.3390/nu7043011

[8] Hewison, M. (2011) Vitamin D and Innate and Adaptive Immunity. Vitamins and Hormones, 86, 23-62.

[9] Mirzakhani, H., Al-Garawi, A., Weiss, S.T. and Litonjua, A.A. (2015) Vitamin D and the Development of Allergic Disease: How Important Is It? Clinical \& Experimental Allergy, 45, 114-125. https://doi.org/10.1111/cea.12430

[10] Setiati, S. (2008) Vitamin D Status among Indonesian Elderly Women Living in Institutionalized Care Units. Acta Medica Indonesiana, 40, 78-83.

[11] Bikle, D. (2000) Vitamin D: Production, Metabolism, and Mechanisms of Action. In: De Groot, L.J., Chrousos, G., Dungan, K., et al., Eds., Endotext, MDText.com, Inc., South Dartmouth.

[12] Puri, S., Marwaha, R.K., Agarwal, N., Tandon, N., Agarwal, R., Grewal, K., et al. (2008) Vitamin D Status of Apparently Healthy Schoolgirls from Two Different Socioeconomic Strata in Delhi: Relation to Nutrition and Lifestyle. British Journal of Nutrition, 99, 876-882. https://doi.org/10.1017/S0007114507831758

[13] Yenigun, A., Dadaci, Z. and Oncel, M. (2015) Plasma Vitamin D Levels of Patients with Allergic Rhino-Conjunctivitis with Positive Skin Prick Test. The American Journal of Rhinology \& Allergy, 29, e46-e49. https://doi.org/10.2500/ajra.2015.29.4164

[14] Vatankhah, V., Lotfizadeh, M., Iranpoor, H., Jafari, F. and Khazraei, H. (2016) Comparison Vitamin D Serum Levels in Allergic Rhinitis Patients with Normal Population. Revue Française d Allergologie, 56, 539-543.

[15] Kalayci, O., Yorgancioglu, A., Kalyoncu, F., Khaltaev, A.N. and Bousquet, J. (2008) Allergic Rhinitis and Its Impact on Asthma Update (ARIA 2008): The Turkish Perspective. The Turkish Journal of Pediatrics, 50, 307-312.

[16] Modh, D., Katarkar, A., Thakkar, B., Jain, A., Shah, P. and Joshi, K. (2014) Role of Vitamin D Supplementation in Allergic Rhinitis. Indian Journal of Allergy, Asthma 
and Immunology, 28, 580-590.

[17] Kim, Y.H., Kim, K.W., Kim, M.J., Sol, I.S., Yoon, S.H., Ahn, H.S., et al. (2016) Vitamin D Levels in Allergic Rhinitis: A Systematic Review and Meta-Analysis. Pediatric Allergy and Immunology, 27, 580-590. https://doi.org/10.1111/pai.12599

[18] Tham, E.H., Lee, A.J. and Bever, H.V. (2016) Aeroallergen Sensitization and Allergic Disease Phenotypes in Asia. Asian Pacific Journal of Allergy and Immunology, 34, 181-189.

[19] Bikle, D.D. (2014) Vitamin D Metabolism, Mechanism of Action, and Clinical Applications. Chemistry \& Biology, 21, 319-329.

[20] Oren, E., Banerji, A. and Camargo, C.A. (2008) Vitamin D and Atopic Disorders in an Obese Population Screened for Vitamin D Deficiency. Journal of Allergy and Clinical Immunology, 121, 533-534.

[21] Wjst, M. and Hypponen, E. (2007) Vitamin D Serum Levels and Allergic Rhinitis. Allergy, 62, 1085-1086. https://doi.org/10.1111/j.1398-9995.2007.01437.x

\section{List of Abbreviations}

25(OH): 25-Dihydroxyvitamin D3

BMI: Body Mass Index

GM-CSF: Granulocyte-Macrophage Colony Stimulating Factor

IL: Interleukin

Th: T-Helper Cell

Submit or recommend next manuscript to OALib Journal and we will provide best service for you:

- Publication frequency: Monthly

- 9 subject areas of science, technology and medicine

- Fair and rigorous peer-review system

- Fast publication process

- Article promotion in various social networking sites (LinkedIn, Facebook, Twitter, etc.)

- Maximum dissemination of your research work

Submit Your Paper Online: Click Here to Submit

Or Contact service@oalib.com 